\title{
Micellar Liquid Chromatographic Determination of Lamivudine, Indinavir and Ketoconazole in Dosage Forms and Biological Fluids
}

\section{Wael Talaat*}

Department of Pharmaceutical Analytical Chemistry, Faculty of Pharmacy, Damanhour University, Damnhour, 25511, Egypt

\begin{abstract}
A simple, reversed phase high performance liquid chromatographic method has been developed for the determination of lamivudine, indinavir and ketokonazole in pharmaceutical preparations, human plasma and urine. The method was conducted using A Shim-pack VP-ODS $(150 \times 4.6 \mathrm{~mm}$ i.d) stainless steel column at ambient temperature with ultra violet detection at $225 \mathrm{~nm}$. Micellar mobile phase consisted of $0.07 \mathrm{M}$ sodium dodecyl sulphate , $10 \% \mathrm{n}$-propanol, $0.3 \%$ triethylamine in $0.02 \mathrm{M}$ phosphoric acid $(\mathrm{pH} 4.5)$ was used and pumped at a flow rate of $1.2 \mathrm{~mL} / \mathrm{min}$. The calibration curve was rectilinear over the concentration range of $(0.05-1.0) \mu \mathrm{g} / \mathrm{mL}$ and $(0.2-5.0)$ and $(0.3-5.0) \mu \mathrm{g} / \mathrm{mL}$ lamivudine, indinavir and ketokonazole respectively. The proposed method was successfully applied to the analysis of these drugs in some dosage forms. The method was extended to the in-vitro,
\end{abstract}

Keywords: HPLC; Micellar mobile phase; Biological fluids

\section{Introduction}

The aim of this study was to develop a micellar liquid chromatographic method for the analysis of some coadministered drugs used for the treatment of human immunodeficiency disease (HIV). The studied drugs were lamivudine, ketokonazole and indinavir. The studied compounds were separated and determined in dosage forms and biological fluids. In vivo estimation of these drugs was investigated in patient plasma.

\section{Mobile Phase}

Micellar liquid chromatography (MLC) offering additional advantages over conventional liquid chromatographic methods. It has proved to be a useful technique in the determination of diverse groups of compounds in several matrices including food and biological samples. MLC allows complex matrices to be analysed without the aid of extraction and with direct injection of the physiological samples. Micelles tend to bind proteins competitively, thereby releasing proteinbound drugs and proteins, rather than precipitating into the column. Proteins compounds are solubilized and washed harmlessly away, eluting with the solvent front. MLC utilizes small amounts of organic modifier and generates less amount of toxic waste in comparison to aqueous-organic solvents, so that they are less toxic, non-flammable, biodegradable and relatively inexpensive (green chemistry) [1,2]. Micelles provide hydrophobic and electrostatic (for ionic surfactants) sites of interaction. In the micelles, three sites of solubilisation can be identified: the core (hydrophobic), the surface (hydrophilic) and the palisade layer (the region between the surfactant head groups and the core). Solutes associated to micelles experience a microenvironment that is different from that of bulk solvent. This is reflected by micelleinduced perturbations in solute physicochemical properties, including changes in solubility, acidity, photophysical properties, and reaction rates [3]. Also, the capability of simultaneous separation of hydrophobic and hydrophilic analytes in the same run without a gradient elution [4]. Unfortunately, some drawbacks were reported concerning the chromtographic efficiency and weak elution strength of pure micellar solution [5,6]. Many articles has been reported for determination of drugs in pharmaceutical preparations and biological fluids [7-9].

The proposed mobile phase was composed of a mixture of $0.07 \mathrm{M}$ sodium dodecyl sulphate (SDS), 10\% n-propanol, $0.02 \mathrm{M}$ phosphoric acid and $0.3 \%$ triethylamine. The $\mathrm{pH}$ was adjusted at $\mathrm{pH} 4.5$ by using phosphoric acid or triethylamine. The mixture was then sonicated for $30 \mathrm{~min}$. The resulting transparent mobile phase was filtered through a $0.45 \mu \mathrm{m}$ membrane filter. The proposed method is investigated for the determination of some coadministered drugs for treatment of HIV. Ketoconazole is coadministered with antiretroviral drugs in order to increase their duration as it suppress the liver microsomal enzymes [10]. It can be used for therapeutic dose monitoring, bioavailablity and pharmacokinetic studies of these drugs.

\section{Lamivudine}

Lamivudine (Figure 1) is (2R-cis)-4-Amino-1-[2-(hydroxylmethyl) 1,3-Oxathiolan-5-yl]-2(1H)-pyrimidinone [11]. It is used as antiviral against HIV and hepatitis B. It has less cytotoxicity and greater antiviral activity than other antiviral drugs [12]. The United States Pharmacopoeia (USP) determine lamivudine by HPLC method [13]. The USP mobile phase consists of mixture (95:5) of ammonium Buffer and methanol ( $\mathrm{pH} 3.8$ ) conducted through $\mathrm{C} 18$ column. The flow rate is about $1.0 \mathrm{~mL}$ per minute. The column temperature is maintained at $35^{\circ} \mathrm{C}$. Other HPLC methods were reported [14-22].

\section{Ketokonazole}

Ketokonazole (Figure1) is 1-[4-(4- $\{[(2 R, 4 S)-2-(2,4$-Dichlorophenyl) -2-(1H-imidazol-1-ylmethyl)-1,3-dioxolan-4-yl]methoxy $\}$ phenyl) piperazin-1-yl]ethan-1-one [11]. Ketoconazole is a synthetic, imidazole antifungal medication used primarily to treat fungal infections. It interferes with the fungal synthesis of ergosterol, a constituent of fungal cell membranes, ketoconazole works principally by inhibiting

*Corresponding author: Wael Talaat, Department of Pharmaceutical Analytica Chemistry, Faculty of Pharmacy, Damanhour University, Damnhour, 25511, Egypt, Tel: +20 45 3368069; E-mail: wt.ismail@yahoo.com

Received December 18, 2014; Accepted January 19, 2015; Published January 23, 2015

Citation: Talaat W (2015) Micellar Liquid Chromatographic Determination of Lamivudine Indinavir and Ketoconazole in Dosage Forms and Biological Fluids. Pharm Anal Acta 6: 327. doi:10.4172/2153-2435.1000327

Copyright: (c) 2015 Talaat W. This is an open-access article distributed under the terms of the Creative Commons Attribution License, which permits unrestricted use, distribution, and reproduction in any medium, provided the original author and source are credited. 
<smiles>Nc1ccn(C2CSC(CO)O2)c(=O)n1</smiles><smiles>CC(=O)N1CCN(c2ccc(OCC3COC(Cn4ccnc4)(c4ccc(Cl)cc4Cl)O3)cc2)CC1</smiles>

Structure formula of ketoconazole<smiles>CC(C)(C)NC(=O)[C@@H]1CN(Cc2cccnc2)CCN1C[C@H](O)CC(Cc1ccccc1)C(=O)N[C@H]1c2ccccc2C[C@H]1O</smiles>

Figure 1: Structural formula of the studied drugs.

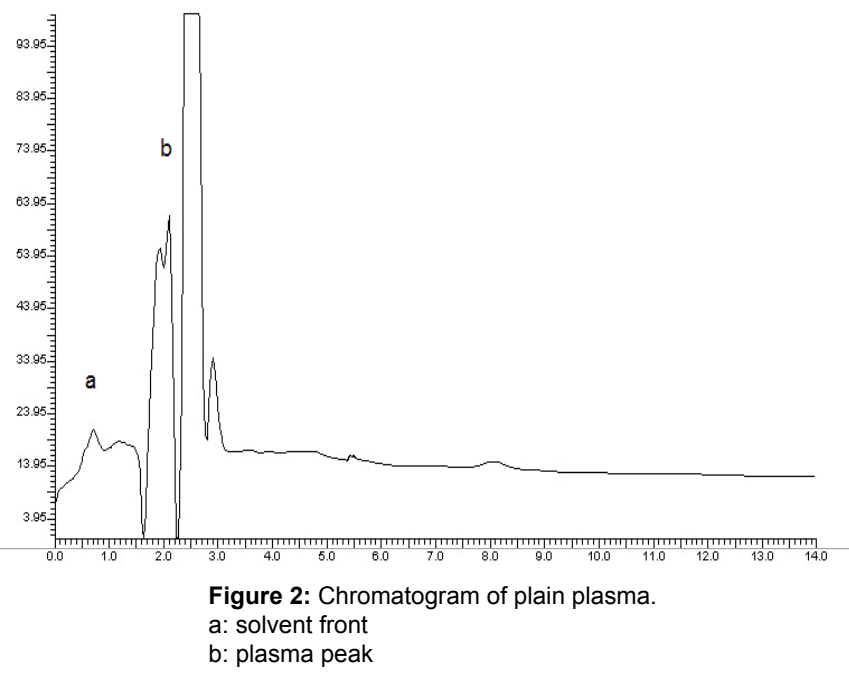

the enzyme cytochrome P450 [12]. Ketoconzole has been titrated potentiometrically using perchloric acid as titrant [5]. Several different articles have been published for the determination of ketoconazole spectrophotometrically [23-25] Voltametrically [26], by HPTLC [27], by HPLC [23,28,29] and by LC-MS [30]. The USP [13] Use mobile phase consists of diisopropylamine in methanol (7:3) conducted through C18 column.

\section{Indinavir}

Indinavir is $2 S)-1-[(2 S, 4 R)-4$-benzyl-2-hydroxy-4- $\{[(1 S, 2 R)$ 2-hydroxy-2,3-dihydro-1 $H$-inden-1-yl] carbamoyl \}butyl]- $N$-tertbutyl-4-(pyridin-3-ylmethyl)piperazine-2-carboxamide [11]. It is a protease inhibitor used as a component of highly active antiretroviral therapy to treat HIV infection and AIDS [12]. Several HPLC [31-33] and LC-MS [34] methods have been reported for the determination of indinavir. The comparison method [31] uses an analytical column of a Phenomenex Luna ${ }^{\circ}$ C8 $10 \mathrm{~mm}$ and a mobile phase was a mixture of di-sodium hydrogen phosphate $(0.01 \mathrm{M})+$ ammonium chloride $(0.4 \%)$ with $\mathrm{pH}$ adjusted to 4.5 (solvent $\mathrm{A}$ ) and acetonitrile(solvent $\mathrm{B}$ ), 68:32, $\mathrm{v} / \mathrm{v}$, pumped at a flow rate of $1.8 \mathrm{~mL} / \mathrm{min}$ through the column.

\section{Experimental}

\section{Reagents}

All chemicals used were of Analytical Reagents grade, and the

- $\quad$ solvents were of HPLC grade.

- $\quad$ Orhtophosphoric acid (Prolabo, Paris, France).

- Methanol (Hipersolv, Merck).

- Sodium dodecyl sulphate (Park Scientific limted, Northompthon, UK), $0.1 \mathrm{M}$ aquous solution was prepared.

- n-Propanol, Ethanol and Triethylamine (Riedel-deHaen, Sleeze, Germany).

- $\quad \mathrm{n}$-Butanol (Honi limited, London, UK).

\section{Materials}

Lamivudine was kindly supplied by Eva Pharmaceuticals, Cairo, Egypt. Ketoconazole and indinavir were purchased from Sigma Aldrich. Lamidine ${ }^{\varpi}$ tablets each labeled to contain $150 \mathrm{mg}$ of lamivudine, Batch No. 1183498. Product of Eva pharmaceuticals and were obtained from the local pharmacy. Nezoral ${ }^{\oplus}$ tablets each labled to contain $200 \mathrm{mg}$ of ketoconazole, Batch No.KN364. Product of Jansen pharmaceuticals and were obtained from the local pharmacy. Crixivan tablets each labeled to contain $200 \mathrm{mg}$ of indinavir, Batch No. 58692. Product of Merck pharmaceuticals and were obtained from the local pharmacy.

\section{Instrument}

The analysis was performed using Shimadzu ${ }^{\mathrm{Tm}}$ LC-20A Series Chromatograph equipped with a Rheodyne injector valve with a $20 \mu \mathrm{L}$ loop and a SPD-20A UV detector operated at $225 \mathrm{~nm}$. LC Workstation (Nishinokyo-Kuwabaracho, Nakagyo-Ku, Kyoto 604-8511, Japan).

\section{Column and mobile phase}

A Shim-pack VP-ODS column $(5 \mu \mathrm{m})(150 \mathrm{~mm} \times 4.6 \mathrm{~mm})$ was used. The micellar mobile phase consisted of a solution containing a mixture of $0.07 \mathrm{M}$ sodium dodecyl sulphate (SDS),10\% n-propanol, $0.02 \mathrm{M}$ phosphoric acid and $0.3 \%$ triethylamine. The $\mathrm{pH}$ was adjusted at $\mathrm{pH} 4.5$ by using phosphoric acid or triethylamine. The mixture was then sonicated for $30 \mathrm{~min}$. The resulting transparent mobile phase was filtered through a $0.45 \mu \mathrm{m}$ membrane filter (Millipore, Ireland). The micellar mobile phase was freshly prepared. Column stabilization was done by running the mobile phase for $1 \mathrm{hr}$. in order to obtain stable baseline. The column hold up value was the first deviation of the base line obtained. 


\section{Standard solutions}

Stock solutions of lamivudine, ketoconazole and indinavir were prepared by dissolving $10.0 \mathrm{mg}$ of the drug in methanol and complete to $25.0 \mathrm{~mL}$ in volumetric flask with same solvent. These stock solutions were further diluted with the mobile phase to obtain the working concentration range $0.05-1.0 \mu \mathrm{g} / \mathrm{mL}$ and $0.3-5.0$ and 0 . 2-5.0 for lamivudine, ketoconzole and indinavir respectively. The stock solutions were found to be stable for at least one week when kept in the refrigerator.The stability of the stock solution was checked through elution of each drug alone. There is no indication of any decomposition of the drugs in the samples.

\section{General Procedures}

\section{Construction of calibration graph}

Working solutions containing concentration ranges of (0.05-1.0 $\mu \mathrm{g} / \mathrm{mL}$ and $(0.3-5.0)$ for lamivudine, ketoconzole respectively were prepared by serial dilution of the stock solutions together with an aliquot of internal standard solution containing $0.1 \mu \mathrm{g} / \mathrm{mL}$ indinavir. 20 $\mu \mathrm{L}$ aliquots were injected (triplicate) and eluted with the mobile phase under the previous chromatographic conditions. A plot of the peak area ratio between the drug and internal standard versus concentration of the drug is made to obtain the standard calibration curve. Alternatively, the regression equation was derived. For constructing a calibration curve for indinavir, $0.1 \mu \mathrm{g} / \mathrm{mL}$ lamivudine was used as internal standard and complete the procedure as mentioned above.

\section{Analysis Lamidine, Nezoral and Crixivan tablets and capsules}

Ten tablets or the contents of ten capsules were accurately weighed, finely pulverized and mixed well. Aliquot quantities of the powder equivalent to $150 \mathrm{mg}, 200 \mathrm{mg}$ and $200 \mathrm{mg}$ of lamivudine, ketoconalzole and indinavir were transferred to a $100 \mathrm{~mL}$ volumetric flask. The drugs were extract with $80 \mathrm{~mL}$ of methanol, the flasks were sonicated for 20 min. Filter into $100 \mathrm{~mL}$ volumetric flask and complete to the volume with methanol. Aliquots of this solution were diluted with the mobile phase and the internal standard $(0.1 \mu \mathrm{g} / \mathrm{mL}$ indinavir) was added to lamidine and nezoral extracts. $20 \mu \mathrm{l}$ were injected (triplicate) and eluted with the mobile phase. The nominal concentration was obtained from the corresponding regression equation. For the determination of indinavir in tablets, the previous procedure was conducted with using $0.1 \mu \mathrm{g} / \mathrm{mL}$ lamivudine as internal standard.

\section{Analysis of lamivudine, ketoconalzole and indinavir in spiked plasma and urine}

$0.5 \mathrm{~mL}$ aliquots of sample plasma was transferred into series of centrifuge tubes, spiked with the working concentrations of the drugs, $0.1 \mu \mathrm{g} / \mathrm{mL}$ indinavir (internal standard), $1.0 \mathrm{~mL}$ of acetonitrile was added, then centrifuged at $4000 \mathrm{rpm}$ for $20 \mathrm{~min}$ at room temperature. The supernatant solutions were aspirated and filtered using a microfilter paper. $20 \mu$ l were injected (triplicate) and eluted with the mobile phase. The nominal concentration was obtained from the corresponding regression equation. For the determination of indinavir in plasma, the previous procedure was conducted with using $0.1 \mu \mathrm{g} / \mathrm{mL}$ lamivudine as internal standard.

\section{Analysis of lamivudine, ketoconalzole and indinavir in patient samples}

Lamidine $15 \mathrm{mg}$ and nezoral $200 \mathrm{mg}$ were administered to a healthy volunteer (males 31 years old) in different days after 8 hours of fasting. A blood sample was withdrawn in the morning before administration of drug as blank. $10 \mathrm{~mL}$ Blood samples were collected after several time intervals; $30 \mathrm{~min} ., 1 \mathrm{hr}, 2 \mathrm{hrs}, 3 \mathrm{hrs}, 4$ and $5 \mathrm{hrs}$ after drug administration. The samples were drawn into test tubes containing sodium citrate as anticoagulant and centrifuged at 2000 $\mathrm{rpm}$ for $20 \mathrm{~min}$. The supernatant plasma was transferred into test tubes, $0.1 \mu \mathrm{g} / \mathrm{mL}$ indinavir (internal standard) was added. The procedure of spiked plasma was performed. Crixivan ${ }^{\star} 200 \mathrm{mg}$ was determined in patient plasma by conducting the previous procedure using $0.1 \mu \mathrm{g} / \mathrm{mL}$ lamivudine as internal standard. The plasma samples were analyzed directly after withdrawing and treatment without the need of freezethaw cycles. The study was done on the available volunteer and it can be extended for further applications.

\section{Results and Discussion}

The micellar mobile phase was selected due to its previously mentioned advantages [1-4] especially the possibility of direct injection of physiological samples. The proposed method is the only one developed for the simultaneous separation and determination of the studied drugs in biological fluids. In addition of being more sensitive than the other methods.

The drug peaks are eluted at retension times of 3.8, 6.1 and 6.9 for lamivudine, ketoconazole and indinavir respectively. The peaks are separated from plasma peak and are well resolved with resolution factors of 3.83 and 1.33 for lamivudine, ketoconazole and ketoconazole, indinavir respectively (Figures 2 and 3 ). The other resolution factors were calculated between the peak of the drug and the preceding peak.

\section{Ultra Violet (UV) detection}

Several wavelengths were investigated and the wavelength 225 $\mathrm{nm}$ was used as it provides high sensitivity for the determination of ketconazole and good sensitivities for the other drugs.

\section{Study of the experimental parameters}

The experimental parameters affecting the chromatographic separation of the drugs were studied and optimized. These variables including mobile phase, flow rate and linearity range. Variables were optimized by changing each in turn, while keeping all others constant to obtain the highest number of theoretical plates and good resolution. The optimum condition was using of $0.07 \mathrm{M}$ sodium dodecyl sulphate

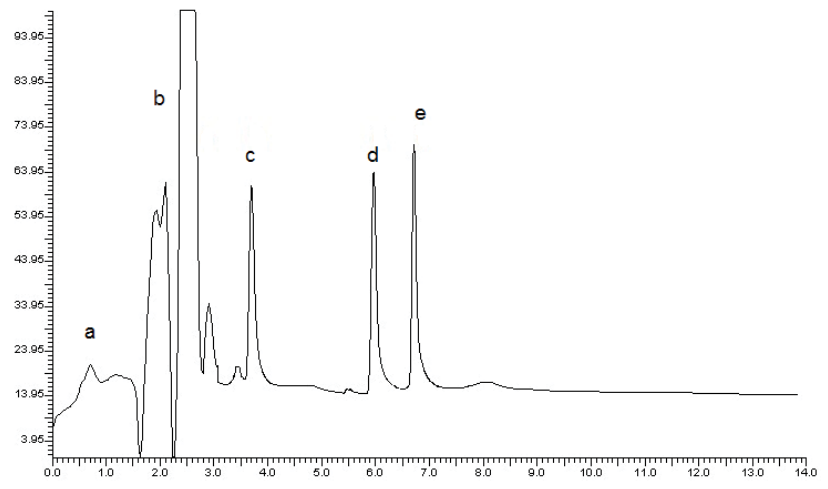

Figure 3: Chromatogram of the studied drugs in patient plasma after 2 hours.

a: solvent front

b: plasma peak

$c$ : Lamivudine

d: ketoconazole

e: indinavir 
Citation: Talaat W (2015) Micellar Liquid Chromatographic Determination of Lamivudine, Indinavir and Ketoconazole in Dosage Forms and Biological Fluids. Pharm Anal Acta 6: 327. doi:10.4172/2153-2435.1000327

Page 4 of 8

, $10 \%$ n-propanol, $0.3 \%$ triethylamine in $0.02 \mathrm{M}$ phosphoric acid ( $\mathrm{pH}$ 4.5), the mobile phase was pumped at a flow rate of $1.2 \mathrm{~mL} / \mathrm{min}$ (Table 1 ).

\section{Analytical validation}

Linearity of the method: After optimizing the conditions, it was found that the relation between the peak area ratios and the final concentrations of the drugs were linear over the ranges $(0.03-1.0)$ $\mu \mathrm{g} / \mathrm{mL}$ and $(0.2-5.0)$ and $(0.3-5.0) \mu \mathrm{g} / \mathrm{mL}$ lamivudine, indinavir and ketokonazole respectively. Linear regression of analysis of results gave the following equation:

Peak area ratio $=0.01+7.4 \mathrm{C}$,

$\mathrm{r}=0.9999$ for lamivudine

Peak area ratio $=0.03+12.7 \mathrm{C}$

$\mathrm{r}=0.9999$ for ketokonazole

Peak area ratio $=0.03+9.6 \mathrm{C}$

$\mathrm{r}=0.9999$ for indinavir

where,

$\mathrm{C}=$ concentration in $\mu \mathrm{g} / \mathrm{mL}$

$\mathrm{r}=$ correlation coefficient
The results of the statistical analysis of regression data for pure samples, such as standard deviation of the slope $\left(\mathrm{S}_{\mathrm{b}}\right)$ and standard deviation of intercept $\left(\mathrm{S}_{\mathrm{a}}\right)$ and the standard deviation of residuals $(\mathrm{Sy} / \mathrm{x})$ were calculated and were found to be $0.2,0.012,0.016$ for lamivudine, $0.3,0.03,0.04$ for ketoconazole $0.22,0.06,0.07$ for indinavir. The small values of the figures point out to low scattering of the points around the calibration.

\section{Accuracy and precision}

The proposed method was evaluated by studying the accuracy as percent relative error (\% Er) and precision as percent relative standard deviation (\% RSD) [35]. The results of intraday and interday accuracy and precision for the method are summarized in Table 2. The results show low percent relative error (\% Er) and percent relative standard deviation (\% RSD) indicating high accuracy and precision. The accuracy of the proposed method was in good agreement with the official and comparison methods [5,23] (Table 3).

\section{Limits of detection and quantification}

The limit of detection (LOD) and quantification (LOQ) were calculated form the calibration curve according to the formula $\mathrm{LOD}=3.3 \mathrm{~S}_{\mathrm{a}} / \mathrm{b}$ and $\mathrm{LOQ}=10 \mathrm{~S} / \mathrm{b}[35]$ respectively. where $\mathrm{S}_{\mathrm{a}}$ is the standard deviation of the intercept of the regression line, $\mathrm{b}$ is the slope

\begin{tabular}{|c|c|c|c|c|c|c|c|}
\hline \multirow{2}{*}{\multicolumn{2}{|c|}{ Experimental parameter }} & \multicolumn{3}{|c|}{ Number of theoretical plates } & \multicolumn{3}{|c|}{ Capacity factor $K^{\top}$} \\
\hline & & \multirow{2}{*}{$\begin{array}{l}\text { LAM } \\
2360\end{array}$} & \multirow{2}{*}{$\begin{array}{r}\text { KCZ } \\
2880\end{array}$} & \multirow{2}{*}{$\begin{array}{r}\text { IDV } \\
4310\end{array}$} & \multirow{2}{*}{$\begin{array}{l}\text { LAM } \\
4.40\end{array}$} & \multirow{2}{*}{$\begin{array}{r}\text { KCZ } \\
7.76\end{array}$} & \multirow{2}{*}{$\begin{array}{l}\text { IDV } \\
9.0\end{array}$} \\
\hline \multirow{6}{*}{$\mathrm{pH}$} & 3.0 & & & & & & \\
\hline & 4.0 & 2410 & 3150 & 4470 & 4.41 & 7.75 & 9.0 \\
\hline & 4.5 & 2470 & 3240 & 4580 & 4.43 & 7.71 & 8.94 \\
\hline & 5.0 & 2435 & 3210 & 4450 & 4.38 & 7.60 & 8.80 \\
\hline & 6 & 2360 & 2910 & 4360 & 4.38 & 7.60 & 8.90 \\
\hline & 7.0 & 2310 & 2650 & 4280 & 4.40 & 7.58 & 8.90 \\
\hline \multirow{5}{*}{ SDS Conc. } & 0.05 & 2340 & 3170 & 4450 & 5.0 & 8.3 & 9.7 \\
\hline & 0.07 & 2470 & 3240 & 4580 & 4.43 & 7.71 & 8.94 \\
\hline & 0.1 & 2440 & 3120 & 4420 & 3.85 & 7.3 & 8.3 \\
\hline & 0.12 & 2350 & 2920 & 4320 & 3.0 & 6.4 & 7.6 \\
\hline & 0.15 & 2240 & 2840 & 4110 & 2.6 & 6.0 & 7.0 \\
\hline \multirow{4}{*}{ Type of organic } & Methanol & 1180 & 1850 & 2280 & 4.6 & 8.0 & 9.5 \\
\hline & Ethanol & 2250 & 2650 & 3110 & 4.5 & 7.9 & 9.2 \\
\hline & Propanol & 2470 & 3240 & 4580 & 4.43 & 7.71 & 8.94 \\
\hline & Butanol & 2340 & 2830 & 3240 & 4.40 & 7.4 & 8.7 \\
\hline \multirow{5}{*}{ Propanol } & $5 \%$ & 1980 & 2410 & 3840 & 5.5 & 8.2 & 9.6 \\
\hline & $8 \%$ & 2330 & 3140 & 4150 & 4.8 & 8.0 & 9.3 \\
\hline & $10 \%$ & 2470 & 3240 & 4580 & 4.43 & 7.71 & 8.94 \\
\hline & $12 \%$ & 2410 & 3190 & 4260 & 3.9 & 7.3 & 8.6 \\
\hline & $15 \%$ & 2220 & 2550 & 3570 & 3.5 & 6.7 & 8.2 \\
\hline \multirow{5}{*}{ Flow rate } & 0.8 & 1340 & 1180 & 2330 & 6.7 & 11.5 & 13.4 \\
\hline & 1.0 & 2110 & 2660 & 3880 & 5.3 & 9.3 & 10.7 \\
\hline & 1.2 & 2470 & 3240 & 4580 & 4.43 & 7.71 & 8.94 \\
\hline & 1.5 & 2310 & 2740 & 3940 & 3.54 & 6.2 & 7.2 \\
\hline & 1.8 & 2010 & 2110 & 2140 & 2.9 & 5.2 & 6.0 \\
\hline \multicolumn{2}{|c|}{ Experimental parameter } & \multicolumn{6}{|c|}{ Selectivity factor $(\alpha)$} \\
\hline
\end{tabular}


Citation: Talaat W (2015) Micellar Liquid Chromatographic Determination of Lamivudine, Indinavir and Ketoconazole in Dosage Forms and Biological Fluids. Pharm Anal Acta 6: 327. doi:10.4172/2153-2435.1000327

Page 5 of 8

\begin{tabular}{|c|c|c|c|c|c|}
\hline \multirow{7}{*}{$\mathrm{pH}$} & & LAM & $\mathrm{KCZ}$ & $\mathrm{KCZ}$ & IDV \\
\hline & 3.0 & \multicolumn{2}{|l|}{1.75} & \multicolumn{2}{|l|}{1.17} \\
\hline & 4.0 & \multicolumn{2}{|l|}{1.74} & \multicolumn{2}{|l|}{1.17} \\
\hline & 4.5 & \multicolumn{2}{|l|}{1.74} & \multicolumn{2}{|l|}{1.16} \\
\hline & 5.0 & \multicolumn{2}{|l|}{1.74} & \multicolumn{2}{|l|}{1.14} \\
\hline & 6 & \multicolumn{2}{|l|}{1.75} & \multicolumn{2}{|l|}{1.15} \\
\hline & 7.0 & \multicolumn{2}{|l|}{1.75} & \multicolumn{2}{|l|}{1.15} \\
\hline \multirow{5}{*}{ SDS Conc. } & 0.05 & \multicolumn{2}{|l|}{1.66} & \multicolumn{2}{|l|}{1.17} \\
\hline & 0.07 & \multicolumn{2}{|l|}{1.74} & \multicolumn{2}{|l|}{1.16} \\
\hline & 0.1 & \multicolumn{2}{|l|}{1.90} & 1.14 & \\
\hline & 0.12 & 2.13 & & 1.19 & \\
\hline & 0.15 & 2.31 & & 1.17 & \\
\hline & Methanol & 1.74 & & 1.19 & \\
\hline & Ethanol & 1.76 & & 1.16 & \\
\hline Type of organic & Propanol & 1.74 & & 1.16 & \\
\hline modifier & Butanol & 1.70 & & 1.18 & \\
\hline & $5 \%$ & 1.50 & & 1.17 & \\
\hline & $8 \%$ & 1.70 & & 1.16 & \\
\hline Propanol & $10 \%$ & 1.74 & & 1.16 & \\
\hline & $12 \%$ & 1.90 & & 1.18 & \\
\hline Conc. & $15 \%$ & 1.91 & & 1.22 & \\
\hline & 0.8 & 1.72 & & 1.17 & \\
\hline & 1.0 & 1.75 & & 1.15 & \\
\hline Flow rate & 1.2 & 1.74 & & 1.16 & \\
\hline$(\mathrm{ml} / \mathrm{min})$ & 1.5 & 1.75 & & 1.16 & \\
\hline (mL/min.) & 1.8 & 1.80 & & 1.15 & \\
\hline Experim & parameter & & & factor (Rs) & \\
\hline & & LAM & KCZ & $\mathrm{KCZ}$ & IDV \\
\hline & 3.0 & 3.80 & & 1.30 & \\
\hline & 4.0 & 3.81 & & 1.30 & \\
\hline & 4.5 & 3.83 & & 1.33 & \\
\hline $\mathrm{pH}$ & 5.0 & 3.80 & & 1.32 & \\
\hline & 6 & 3.81 & & 1.30 & \\
\hline & 7.0 & 3.81 & & 1.30 & \\
\hline & 0.05 & 4.5 & & 2.1 & \\
\hline & 0.07 & 3.83 & & 1.33 & \\
\hline & 0.1 & 3.1 & & 1.26 & \\
\hline SUS Conc. & 0.12 & 2.5 & & 1.16 & \\
\hline & 0.15 & 2.0 & & 1.0 & \\
\hline Type of organic & Methanol & 2.8 & & 1.11 & \\
\hline modifier & Ethanol & 3.2 & & 1.20 & \\
\hline & Propanol & 3.83 & & 1.33 & \\
\hline & Butanol & 3.9 & & 1.40 & \\
\hline & $5 \%$ & 5.1 & & 1.8 & \\
\hline Propanol & $8 \%$ & 4.2 & & 1.50 & \\
\hline & $10 \%$ & 3.83 & & 1.33 & \\
\hline Conc. & $12 \%$ & 3.1 & & 1.28 & \\
\hline & $15 \%$ & 2.66 & & 1.21 & \\
\hline & 0.8 & 5.7 & & 2.0 & \\
\hline & 1.0 & 4.60 & & 1.60 & \\
\hline & 1.2 & 3.83 & & 1.33 & \\
\hline (mL/min.) & 1.5 & 3.10 & & 1.1 & \\
\hline & 1.8 & 2.55 & & 0.9 & \\
\hline & & $\begin{array}{l}\text { Table 1: Effect of different } \\
\text { LAM: Lamivudine } \\
\text { KCZ: Ketoconazole } \\
\text { IDV: Indinavir }\end{array}$ & lental para & e column efficiency. & \\
\hline
\end{tabular}


Citation: Talaat W (2015) Micellar Liquid Chromatographic Determination of Lamivudine, Indinavir and Ketoconazole in Dosage Forms and Biological Fluids. Pharm Anal Acta 6: 327. doi:10.4172/2153-2435.1000327

Page 6 of 8

of the calibration curve. The limit of detections were $0.005,0.008$, 0.021 , for lamivudine, ketoconazole and indinavir, respectively. The limit of quantification values were $0.016,0.024,0.062$, for lamivudine , ketoconazole and indinavir, respectively.

\section{Robustness}

The robustness of the method was studied according to the United State Pharmacopoeia [13] and no significant effect on assay data performance was observed with change of $\mathrm{pH}$ (4-5), flow rate (1-1.5mL) and mobile phase composition (0.05-0.1 M SDS), (8\%-12\%propanol) (Table 4).

\section{System suitability}

System suitability parameters were measured using three injections of reference solutions of the studied drugs to verify the system performance. The $\%$ RSD values were calculated for the number of theoretical plates, capacity factor, tailing factor and retention time Table 5.

\section{Application to dosage forms}

The proposed method was successfully applied for the determination of the studied drugs in tablets and capsules. The results shown in Table 3 are in good agreement with those obtained by the official USP method [13] for the determination of lamivudine, ketoconazole comparison methods [31] for the determination of indinavir. The proposed method is fairly sensitive compared with the official and comparison methods.

\section{Content uniformity testing}

Due to the high precision of the method, and its ability to rapidly estimate the concentration of the drug in a single tablet and capsule extract with sufficient accuracy, the method is suited for content uniformity testing which is a time consuming process when using conventional assay technique. The steps of the test were adopted according to the United States Pharmacopoeia procedure. The acceptance value AV was calculated for each of the commercially available tablets and it was found to be smaller than the maximum allowed acceptance value L1.The results demonstrated reasonable drug uniformity as shown in Table 6.

\section{Application to spiked biological fluids}

The high sensitivity attained by the proposed method allows determination of the drugs in biological fluids with high percentage of recovery Table 7 .

\section{Application to patient samples}

The plasma samples obtained from the volunteer were investigated using the regression equation of spiked plasma. The maximum plasma level reached after $1 \mathrm{hr}$ for lamivudine, $2 \mathrm{hr}$ for indinavir, and ketoconazole. Hence, the proposed method allows monitoring of the therapeutic drug levels in plasma, bioavailability and pharmacokinetic studies (Figures 2 and 3) (Table 8). The obtained results are with good agreement with the reported plasma concentrations [10,12,31].

\section{Stability}

The stability of the methanolic and aqueous sample solutions at room temperature $\left(25^{\circ} \mathrm{C}\right)$ for 24 hour after preparation, was verified by reassaying them. There is no indication of any decomposition of the drugs in the samples.

\begin{tabular}{|c|c|c|c|c|c|c|c|c|c|c|c|}
\hline \multicolumn{4}{|c|}{ LAMIVUDINE } & \multicolumn{4}{|c|}{ KETOCONAZOLE } & \multicolumn{4}{|c|}{ INDIMAVIR } \\
\hline $\begin{array}{c}\text { Conc. } \\
\text { added } \mu \mathrm{g} / \mathrm{mL}\end{array}$ & $\%$ Found & $\%$ RSD & $\% \mathrm{Er}$ & $\begin{array}{c}\text { Conc. } \\
\text { added } \mu \mathrm{g} / \mathrm{mL}\end{array}$ & $\%$ Found & $\%$ RSD & $\% \mathrm{Er}$ & $\begin{array}{c}\text { Conc. } \\
\text { added } \mu \mathrm{g} / \mathrm{mL}\end{array}$ & $\%$ Found & $\%$ RSD & $\% \mathrm{Er}$ \\
\hline Intraday & & & & Intraday & & & & Intraday & & & \\
\hline 0.03 & $99.90 \pm 0.22$ & 0.22 & 0.3 & 0.3 & $99.50 \pm 0.32$ & 0.32 & 0.18 & 0.18 & $99.80 \pm 0.23$ & 0.23 & 0.13 \\
\hline 0.5 & $100.10 \pm 0.26$ & 0.26 & 0.8 & 0.8 & $100.20 \pm 0.40$ & 0.40 & 0.23 & 0.23 & $100.20 \pm 0.3$ & 0.27 & 0.16 \\
\hline 1.00 & $99.88 \pm 00.21$ & 0.21 & 5.00 & 5.00 & $99.90 \pm 0.41$ & 0.41 & 0.24 & 0.24 & $99.68 \pm 0.26$ & 0.26 & 0.15 \\
\hline Interday & & & & Interday & & & & Interday & & & \\
\hline 0.03 & $100.20 \pm 0.24$ & 0.24 & 0.14 & 0.3 & $100.31 \pm 0.32$ & 0.32 & 0.18 & 0.3 & $100.23 \pm 0.3$ & 0.25 & 0.14 \\
\hline 0.5 & $100.13 \pm 0.20$ & 0.20 & 0.12 & 0.8 & $99.62 \pm 0.33$ & 0.33 & 0.19 & 0.8 & $100.15 \pm 0.2$ & 0.23 & 0.13 \\
\hline 1.00 & $99.5 \pm 0.27$ & 0.27 & 0.16 & 5.00 & $99.62 \pm 0.3$ & 0.42 & 0.24 & 5.00 & $100.15 \pm 0$ & 0.27 & 0.16 \\
\hline
\end{tabular}

Table 2: Intraday and inter day precision for the proposed method for the determination of the studied drugs. Each result is the average of three separate determinations.

\begin{tabular}{|c|c|c|c|c|c|c|c|c|c|c|c|}
\hline \multicolumn{4}{|c|}{ LAMIDINE 150 MG } & \multicolumn{4}{|c|}{ NEZORAL 200 MG } & \multicolumn{4}{|c|}{ CRIXIVAN 200 MG } \\
\hline \multicolumn{2}{|c|}{ Proposed method } & \multicolumn{2}{|c|}{ Official method(13) } & \multicolumn{2}{|c|}{ Proposed method } & \multicolumn{2}{|c|}{ Official method(13) } & \multicolumn{2}{|c|}{ Proposed method } & Comparisor & $\operatorname{method}^{(31)}$ \\
\hline $\begin{array}{c}\text { Amont } \\
\text { taken, } \mu \mathrm{g} / \\
\mathrm{mL}\end{array}$ & $\begin{array}{c}\% \\
\text { Found }\end{array}$ & $\begin{array}{c}\text { Amont } \\
\text { taken, } \mu \mathrm{g} / \\
\mathrm{mL}\end{array}$ & $\begin{array}{c}\% \\
\text { Found }\end{array}$ & $\begin{array}{c}\text { Amont } \\
\text { taken, } \mu \mathrm{g} / \\
\mathrm{mL}\end{array}$ & $\begin{array}{c}\% \\
\text { Found }\end{array}$ & $\begin{array}{c}\text { Amont } \\
\text { taken, } \mu \mathrm{g} / \\
\mathrm{mL}\end{array}$ & $\begin{array}{c}\% \\
\text { Found }\end{array}$ & $\begin{array}{c}\text { Amont taken, } \\
\mu \mathrm{g} / \mathrm{mL}\end{array}$ & $\begin{array}{c}\% \\
\text { Found }\end{array}$ & $\begin{array}{c}\text { Amont } \\
\text { taken, } \mu \mathrm{g} / \\
\mathrm{mL}\end{array}$ & $\begin{array}{c}\% \\
\text { Found }\end{array}$ \\
\hline 0.03 & 100.30 & 1.00 & 99.90 & 0.3 & 100.30 & 1.0 & 99.50 & 0.3 & 99.30 & 0.5 & 99.82 \\
\hline 0.08 & 99.60 & 4.00 & 99.80 & 0.8 & 99.30 & 2.0 & 99.80 & 0.8 & 99.52 & 0.8 & 99.20 \\
\hline 0.5 & 99.83 & 8.00 & 100.41 & 2.00 & 99.82 & 3.0 & 100.25 & 2.00 & 99.91 & 1.00 & 100.50 \\
\hline 1.00 & 99.77 & 10.0 & 99.42 & 5.00 & 99.71 & 4.0 & 100.15 & 5.00 & 100.10 & & 100.13 \\
\hline mean $\pm S D$ & $99.91 \pm 0.3$ & & $99.90 \pm 0.35$ & mean $\pm S D$ & $99.80 \pm 0.33$ & & $99.90 \pm 0.38$ & mean $\pm S D$ & $99.70 \pm 0.41$ & & $99.90 \pm 0.50$ \\
\hline t-test & $(2.45)^{*}$ & $(0.26)$ & & t-test & $(2.45)^{*}$ & $(1.4)$ & & test & $(2.45)^{\star}$ & (1.35) & \\
\hline F-test & $(9.27)^{\star}$ & (1.31) & & F-test & $(9.27)^{*}$ & $(1.563)$ & & F-test & $(9.27)^{*}$ & $(1.5)$ & \\
\hline
\end{tabular}

Table 3: Application of the proposed and comparison method to determination of the studied drugs in dosage forms. 
Citation: Talaat W (2015) Micellar Liquid Chromatographic Determination of Lamivudine, Indinavir and Ketoconazole in Dosage Forms and Biological Fluids. Pharm Anal Acta 6: 327. doi:10.4172/2153-2435.1000327

Page 7 of 8

\begin{tabular}{|c|c|c|c|c|c|c|c|c|c|}
\hline \multirow[b]{2}{*}{ PARAMETERS } & \multicolumn{3}{|c|}{ LAMIVUDINE } & \multicolumn{3}{|c|}{ KETOCONAZOLE } & \multicolumn{3}{|c|}{ INDINAVIR } \\
\hline & Retention time & Theoritical plate & $\begin{array}{l}\text { Capacity } \\
\text { factor }\end{array}$ & Retention time & Theoritical plate & $\begin{array}{l}\text { Capacity } \\
\text { factor }\end{array}$ & Retention time & Theoritical plate & Capacity factor \\
\hline 0.05 MSDS & 4.2 & 2340 & 3.5 & 6.50 & 3170 & 8.3 & 7.50 & 4450 & 9.70 \\
\hline 0.07 MSDS & 3.8 & 2470 & 4.43 & 6.1 & 3240 & 7.71 & 6.9 & 4580 & 8.94 \\
\hline $0.1 \mathrm{MSDS}$ & 3.4 & 2440 & 1.5 & 5.80 & 3120 & 7.30 & 6.5 & 4420 & 8.3 \\
\hline $8 \%$ propanol & 4.1 & 2330 & 4.8 & 6.3 & 3140 & 8.0 & 7.2 & 4150 & 9.3 \\
\hline $10 \%$ propanol & 3.8 & 2470 & 4.43 & 6.1 & 3240 & 7.71 & 6.9 & 4580 & 8.94 \\
\hline $12 \%$ propanol & 3.4 & 2410 & 3.9 & 5.8 & 3190 & 7.30 & 6.7 & 4260 & 8.6 \\
\hline $\mathrm{pH} 4$ & 3.82 & 2410 & 4.45 & 6.2 & 3150 & 7.75 & 7.0 & 4470 & 9.0 \\
\hline $\mathrm{pH} 4.5$ & 3.8 & 2470 & 4.43 & 6.1 & 3240 & 7.71 & 6.9 & 4580 & 8.94 \\
\hline pH 5.0 & 3.7 & 2435 & 4.38 & 6.0 & 3210 & 7.60 & 6.8 & 4450 & 8.8 \\
\hline $1.0 \mathrm{~mL} / \mathrm{min}$ & 4.4 & 2110 & 5.3 & 7.2 & 2260 & 9.3 & 5.50 & 3880 & 10.7 \\
\hline $1.2 \mathrm{~mL} / \mathrm{min}$ & 3.8 & 2470 & 4.43 & 6.1 & 3240 & 7.71 & 6.9 & 4580 & 8.94 \\
\hline $1.5 \mathrm{~mL} / \mathrm{min}$ & 3.2 & 2310 & 3.54 & 5.0 & 2740 & 6.2 & 5.7 & 3940 & 7.2 \\
\hline
\end{tabular}

Table 4: Results of the robustness of the proposed method.

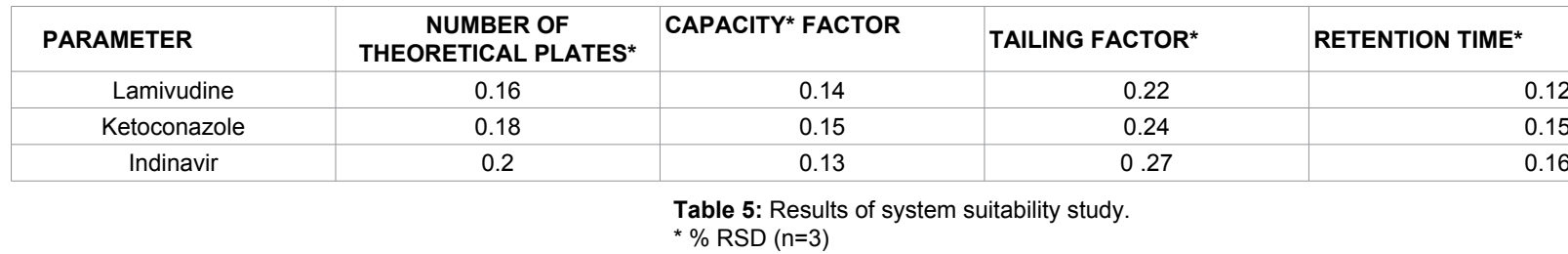

\begin{tabular}{|c|c|c|c|}
\hline \multirow{2}{*}{ PARAMETER } & \multicolumn{3}{|c|}{ PERCENTAGE OF THE LABLE CLAIM } \\
\hline & Lamidine tablets & Nezoral tablets & Crixivan capsules \\
\hline \multirow{10}{*}{ Data } & 99.45 & 101.10 & 101.22 \\
\hline & 99.50 & 100.90 & 100.24 \\
\hline & 100.33 & 99.40 & 99.31 \\
\hline & 100.20 & 99.53 & 100.44 \\
\hline & 100.63 & 100.30 & 99.75 \\
\hline & 99.82 & 99.55 & 100.32 \\
\hline & 99.60 & 101.21 & 99.60 \\
\hline & 99.12 & 99.23 & 99.32 \\
\hline & 100.15 & 99.65 & 99.35 \\
\hline & 100.30 & 99.21 & 99.50 \\
\hline Mean & 99.91 & 100.01 & 99.90 \\
\hline SD & 0.53 & 0.80 & 0.50 \\
\hline \% Error & 0.17 & 0.30 & 0.15 \\
\hline Acceptance & 1.25 & 1.85 & 1.10 \\
\hline \multicolumn{4}{|l|}{ value(AV) } \\
\hline Maximum allowed value(L1) & & 15 & \\
\hline
\end{tabular}

Table 6: Content uniformity testing of Lamivudine, ketoconazole and indinavir in their dosage forms using the proposed method.

\begin{tabular}{|c|c|c|c|c|c|}
\hline \multicolumn{2}{|c|}{ LAMIVUDINE } & \multicolumn{2}{|c|}{ KETOCONAZOLE } & \multicolumn{2}{|c|}{ INDIMAVIR } \\
\hline Conc.added $\mu \mathrm{g} / \mathrm{mL}$ & $\%$ Found & Conc.added $\mu \mathrm{g} / \mathrm{mL}$ & $\%$ Found & Conc.added $\mu \mathrm{g} / \mathrm{mL}$ & $\%$ Found \\
\hline Plasma & & Plasma & & Plasma & \\
\hline 0.03 & 98.90 & 0.3 & 101.31 & 0.3 & 98.70 \\
\hline 0.5 & 101.10 & 0.8 & 99.20 & 0.8 & 101.10 \\
\hline 1.00 & 99.30 & 5.00 & 98.80 & 5.00 & 99.50 \\
\hline mean $\pm S D$ & $99.76 \pm 1.17$ & mean $\pm S D$ & $99.77 \pm 1.35$ & mean $\pm S D$ & $99.77 \pm 1.22$ \\
\hline Urine & & Urine & & Urine & \\
\hline 0.03 & 100.10 & 0.3 & 99.10 & 0.3 & 100.42 \\
\hline 0.5 & 100.50 & 0.8 & 101.20 & 0.8 & 101.15 \\
\hline 1.00 & 99.11 & 5.00 & 98.90 & 5.00 & 99.21 \\
\hline mean $\pm S D$ & $99.9 \pm 0.72$ & mean $\pm \mathrm{SD}$ & $99.73 \pm 1.27$ & mean $\pm S D$ & $100.3 \pm 0.9$ \\
\hline
\end{tabular}

Table 7: Application of the proposed method for the determination of the studied drugs in spiked plasma. 
Citation: Talaat W (2015) Micellar Liquid Chromatographic Determination of Lamivudine, Indinavir and Ketoconazole in Dosage Forms and Biological Fluids. Pharm Anal Acta 6: 327. doi:10.4172/2153-2435.1000327

Page 8 of 8

\begin{tabular}{|c|c|c|c|c|c|c|}
\hline TABLET/TIME & $0.5 \mathrm{HR}$ & $1 \mathrm{HR}$ & $2 \mathrm{HR}$ & $3 \mathrm{HR}$ & $4 \mathrm{HR}$ & $5 \mathrm{HR}$ \\
\hline $\begin{array}{c}\text { lamidine }{ }^{\circledR} 150 \mathrm{mg} \\
\text { tablets }\end{array}$ & 0.90 & 1.61 & 1.51 & 1.1 & 0.83 & 0.41 \\
\hline Nezoral $^{\circledR} 200 \mathrm{mg}$ & 1.8 & 3.1 & 3.4 & 2.8 & 1.9 & 1.5 \\
\hline $\begin{array}{c}\text { Crixivan }{ }^{\circledR} 200 \mathrm{mg} \\
\text { capsules }^{2}\end{array}$ & 0.6 & 1.0 & 1.5 & 0.8 & 0.52 & 0.11 \\
\hline
\end{tabular}

Table 8: Determination of the studied drugs in $\mu \mathrm{g} / \mathrm{mL}$ in patient plasma.

\section{Conclusion}

The proposed method provides simultaneous determination of lamivudine, ketoconazol and indinavir offering additional advantages over comparison methods. The present investigation can be utilized for monitoring of the concentration of the studied drugs in patient plasma. In addition it can be extended for pharmacokinetic studies.

\section{References}

1. Romero JE, Carda-Broch S, Gil-Agusti M, Capella-Piero M, Bose D (2005) Monitoring disopyramide,lidocaine and quinidine by micellar liquid chromatography. Trends Anal Chem 24: 104-109.

2. MeiC, Devasish B, Josep E, Juan P, Maria R et al. (2011) Determination of Putrescine and Tyramine in Fish by Micellar Liquid Chromatography with UV Detection Using Direct Injection. The Open Analytical Chemistry Journal 5: 22-26.

3. Ruiz M, Carda S, Torres J, García M (2009) Retention mechanisms in micellar liquid chromatography. J Chromatog A 1216: 1798-1814.

4. Romero JE, Samuel C, Maria R (2010) Micellar liquid chromatography in bioanalytical chemistry. Contribution to science $6: 105-114$

5. Berthod A (1997) Causes and remediation of reduced efficiency in micellar liquid chromatography. J. Chromatogr. A 780: 191-206.

6. Dorsey JG, DeEchengaray MT, Landy JS (1983) Efficiency enhancement in micellar liquid chromatography. Anal Chem 55: 924-928.

7. Thogchai W, Liawruangrath B (2013) Micellar liquid chromatographic determination of arbutin and hydroquinone in medicinal plant extracts and commercial cosmetic products. International Journal of Cosmetic Science 35: 257-263.

8. Swati D, Devasish B, Shukla SK, Abhilasha Di, Romero JE (2013) Monitoring strychnine and brucine in biochemical samples using direct injection micellar liquid chromatography, Anal Methods 5: 1747-1754.

9. Dalia R (2012) Simultaneous Determination of Metformin, Nateglinide and Gliclazide in Pharmaceutical Preparations Using Micellar Liquid Chromatography. Int J Biomed Sci 8: 144-151.

10. Walker, R. Whittlesea , C. (2008) . Clinical Pharmacy and Therapeutics (4 edn.) Harcourt publishers limited, London.

11. Budavari S (1996) The Merck Index (12 ${ }^{\text {th }}$ edn.) Merk \&Co. Inc, White House Station, NJ.

12. Hardman JG, Gilman AG, Limbird LE (1996) The Pharmacological Bases of Therapeutics ( $9^{\text {th }}$ edn.) MC Graw-Hill, NY.

13. (2007) United State Pharmacopeial convention: United State Pharmacopoiea 30 National Formulary 25, US Pharmacopoiea convention, Rockville, MD.

14. Sharaf M, Eid M, Talaat W (2014) Micellar liquid chromatographic determination of ribavirin, silybin, interferon a $2 \mathrm{~A}$, lamivudine and ursodeoxycholic acid in dosag forms and biologicak fluids. Liquid Chromator and Relat Technol 37: $1-19$.

15. Bengi U, Sibel A (2002) Determination of lamivudine and zidovudine in binary mixturesusing first derivative spectrophotometric, first derivative of the ratiospectra and HPLC-UV method. Analytica Chimica Acta 466: 175-181.

16. Gholamerza B, Shahla M, Amir K, Bahareh M (2005) High performance liquid chromatographic determination of lamivudine in human serum using liquidliquid extraction :application to pharmacokinetic studies. J. Chromatogr B. 823 213-219.

17. Sockalingam A, Narayareddy I, Pitchaimuthu S, Sishaiah K (2005) Simutaneous quantification of stavudine,lamivudine and nevirapine by UV spectroscopy,reversed phase HPLC and HPTLC. Pharm Biomed Anal 39: 801 807
18. Wissen C, Aarnoutse R, Burger D (2005) Simultaneous determination of the HIV nucleoside analogue reverse transcriptase inhibitors lamivudine, didansine, stavudine,zidovudine and abacavir in human plasma by reversed phase HPLC. J. Chromatogr. B 816: 121-129.

19. Vincent B, Philippe M, Philippe C, Ghislaine L, Luigi A (2005) .Simultaneous analysis of several antiretroviral nucleosides in rat plasma byHPLC with UV using acetic acid /hydroxylamine buffer test of this new volatile medium-pH for HPLC-ESI-MS/MS. J. Chromatogr B 821: 132-140.

20. Mahua S, Sateesh K, Ramesh P (2006) Development and validation of RpHPLC and UV spectrophotometeric method of analysis for the quantitative estimation of antiretroviral drugs in pharmaceutical dosage Forms. J Chromatogr 830: 349-355

21. Herve R, Bernard M, Corrinne C, Pierre B (2007) Determination of 19 antiretroviral agents in pharmaceuticals or suspected products with methods using HPLC. J Chromatogr B 850: 376-382.

22. Roa L, Daniel R, Nathan, Marie E, Marisa C, et al. (2008) Metabolism and pharmacokinetics of the combination zidovudine plus lamivudine in the adult Erythrocebus patas moneky determined by LC-MS analysis. Toxicology and Applied Pharmacology 226: 206-211.

23. Gjorgjeska B (2012) Determination of Ketoconazole in tablets by using three different methods. European Medical Health and Pharmaceutical Journal 4 8-13.

24. Rane S, Padmaja (2012) Spectrophotometric method for the determination of ketoconazole based on amplification reactions, J Pharmaceutical Analysis 2: $43-50$.

25. Farhadi K, Malek R (2001) A New spectrophotometric Method for the Determination of Ketoconazole Based on the Oxidation Reactions, Analytical Sciences 17: 867-372.

26. Shamsipur M, Farhadi K (2000) Adsorptive stripping voltammetric determination of ketoconazole in pharmaceutical preparations and urine using carbon paste electrodes, Analyst 125: 1639-1645.

27. Saysin S, Liawruangrath B, Liawruangrath S (2010) High performance thinlayer chromatographic determination of ketoconazole in pharmaceutical formulations, J Cosmet Sci 61: 367-374.

28. Staub I, Bergold A (2004) Determination of Ketoconazole in Shampoo by High Performance Liquid Chromatography, Acta Farm Bonaerense 2 : 387-392.

29. Heyden Y, Nguyet A, Detaevernier M, Massart D, Vercammen (2002) J Simultaneous determination of ketoconazole and formaldehyde in a shampoo: liquid chromatography method development and validation, J Chromatogr A 958: 191-196.

30. Chen Y, Felder L, Jiang X, Naidong W (2002) Determination of ketoconazole in human plasma by high-performance liquid chromatography-tandem mass spectrometry. J Chromatogr B Analyt Technol Biomed Life Sci. 774: 67-73.

31. Gonçalves T, Fernandes B, Galindo D, Souza V, De Abreu L, et al. (2007) Determination of indinavir in human plasma and its use in pharmacokinetic study. Rev Bras Cienc Farm 43: 159-160.

32. Sarash M, Lopez Y, Mallolas J, Blanco J, Gatell J, et al. (2001) Simultaneous determination of the HIV-protease inhibitors indinavir, amprenavir, ritonavir saquinavir and nelfinavir in human plasma by reversed-phase high-performance liquid chromatography. J Chromatogr B 757: 325-332.

33. Yamada H, Kotaki H, Nakamura T, Iwamoto A ( 2001) Simultaneous determination of the HIV protease inhibitors indinavir, amprenavir, saquinavir ritonavir and nelfinavir in human plasma by high-performance liquid chromatography. J Chromatogr B 755: 85-89.

34. Anura L, Kearney B, Judith A, Gambertoglio J, Aweeka T (2001) An LC-MS-MS method for the determination of indinavir, an HIV-1 protease inhibitor, in human plasma, J Pharmaceutical and Biomedical Analysis 25: 309-315

35. Miller JC, Miller JN (1993) Statistics for Analytical Chemistry (4 ${ }^{\text {th }}$ edn) EllisHowood and prentice Hall, NY. 